Journal of Global Catholicism

Manuscript 1075

\title{
"Give me some beautiful holy images that are colorful, play music, and flash!" The Roma Pilgrimage to Csatka, Hungary
}

István Povedák

Follow this and additional works at: https://crossworks.holycross.edu/jgc

Part of the Catholic Studies Commons, Christianity Commons, Cultural History Commons, Eastern European Studies Commons, European History Commons, Folklore Commons, History of Religion

Commons, History of Religions of Western Origin Commons, Place and Environment Commons, Race and Ethnicity Commons, and the Regional Sociology Commons 


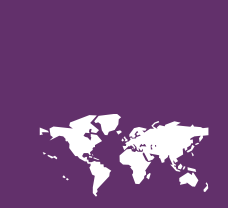

Catholics $£$ Cultures VOLUME 4 I ISSUE 2

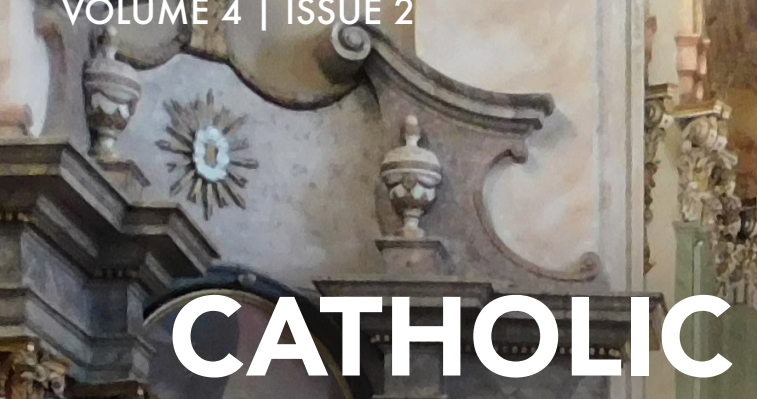

the POLIICS and PRAGMAT

of PLACEMAKING

in EASTERN

ntm

PILGIMAGE añ

Journal of GLOBAL CATHOLICISM

SUMMER 2020

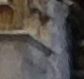




\section{ISTVÁN POVEDÁK}

\section{"Give me some beautiful holy images \\ that are colorful, play music, and flash!" \\ The Roma Pilgrimage to Csatka, Hungary}

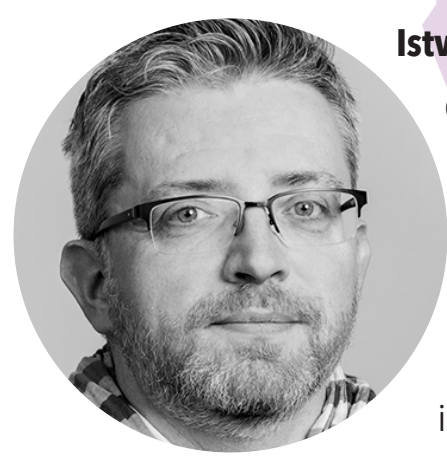

István Povedák is a cultural anthropologist and researcher of religious culture. His Ph.D. dissertation analyzed Hungarian celebrity culture from the folkloristic and religious studies' perspective (2009, Eötvös Lóránd University, Budapest). His books and articles analyze different types of modern mythologies, everyday neo-nationalism, ethnopaganism and Romani culture. He has been serving as the President of Hungarian Cultural Anthropology Association and the Network for Modern Mythologies. Currently he is an Associate Professor at Moholy-Nagy University of Art and Design, Budapest.

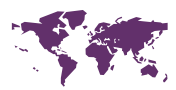


We arrive by car to the small village of Csatka, hidden among the hills of Bakonyalja, two hours from Budapest. We are in one of the isolated, depopulated and relatively backward regions of Hungary. On a narrow bumpy road, police and bodyguards stop our car on the outskirts of the village. We came for the Roma pilgrimage on Nativity Day like everyone else. They tell us where to go and charge us for parking. Hundreds of cars are already standing in the mowed field on the hillside. Next to them are large tents, behind which a generator growls. It is producing electricity for amplifiers. One band in each tent is playing music for the gathering crowd. Whiskey bottles are everywhere on the ground. Many in the crowd are already singing and starting to dance. A little further away from the tents, people dressed for a celebration stand around a table set in the shade of trees. They are visibly affuent, members of the Roma aristocracy. Later, among the merchant tents, we see them again. In the hands of the women there are bouquets of gladioli and lilies, while the men carry huge candles. Everyone is very elegant. The ladies in high heels, silk dresses, make-up, the men in suits, their sunglasses pushed over their heads, each has a glittering piece of jewelry. They are sharply separated from the older Gadjo [non-Roma] pilgrims in casual attire. ${ }^{1}$ They came for the same sacred rite, yet they behave completely differently. They experience holiness elsewhere and differently.

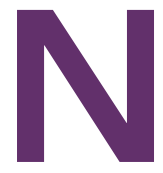

owadays, not only the pilgrimage itself, but also the study of contemporary tendencies and changes in the pilgrimage process are becoming more and more popular. There are both religious and secular reasons behind the "renaissance" of pilgrimages. One generator is obviously the exponential growth of tourism industry, as a result of which religious destinations have also gained outstanding popularity. The popularity of religious tourism has transformed the environment of the most significant traditional pilgrimage sites, where new city districts with shops, restaurants and hotels have risen. In addition to traditional pilgrims, homo turisticus religious (religious tourists), spiritual tourists, and merely experience-seeking tourists have appeared, but the attitude of the local community has also changed in many cases. ${ }^{2}$ The pilgrimage seems to confront general

1 In the Romani language non-Roma are called "Gadjo." Throughout the article I refer to non-Roma (in our case mostly Hungarian) pilgrims as Gadjo.

2 Boris Vukonić, Tourism and Religion (Oxford, New York, Tokyo: Pergamon, 1996), 13. 
38 | "Give me some beautiful holy images that are colorful, play music, and flash!"

The Roma Pilgrimage to Csatka, Hungary

religious processes and increasing at a rapid rate rather than diminishing. Not only are traditional pilgrimage sites attracting more visitors than ever before, but new pilgrimage centers keep on emerging. ${ }^{3}$ While participation in church rituals is declining in Europe, especially in the case of historic Christian churches, attendance at several pilgrimage sites is rising sharply. ${ }^{4}$ As a consequence- - said Stausberg-the invention of pilgrimages has been an important Catholic response to modernity and modernization. ${ }^{5}$ There are several reasons behind the international transformation and the boom in pilgrimages, but one of the main drivers and patterns of these is undoubtedly the growing popularity of El Camino to Santiago de Compostela. ${ }^{6}$ As a result of "caminonization," as Margry called the process, pilgrimages began to be promoted in several regions, and the success of the revitalization of the Camino has now spawned a range of other cultural routes based on religious themes or containing significant links to religious themes such as the Baroque Route in France, the Via Francigena from Northern France to Rome, but pilgrims themselves began to consider the behavior depicted during the Camino de Santiago worldwide as a model. ${ }^{7}$ At the same time, pilgrimages can no longer be interpreted exclusively within the framework of a particular religion. Pilgrimage places are not only visited by adherents of a religion that is organically connected to the site, and the goal of pilgrims is not necessarily to make special contact with the transcendent, to be released from their sins, to deepen in faith, and to be healed

3 Michael Stausberg, Religion and Tourism: Crossroads, Destinations and Encounters (London and New York: Routledge, 2011), 59. https://doi.org/10.4324/9780203854785.

4 Mary Lee Nolan and Sidney Nolan, "Religious Sites as Tourism Attractions in Europe," Annals of Tourism Research 19 (1992): 68-78, https://doi.org/10.1016/0160-7383(92)90107-Z..

5 Stausberg, Religion, 59.

6 For more information see Daniel H. Olsen and Dallen J. Timothy, "Tourism and Religious Journeys," in Tourism, Religion and Spiritual Journeys, eds. Daniel H. Olsen and Dallen J. Timothy (New York: Routledge, 2006), 3-4.

7 Peter Jan Margry, "To Be or not to Be... a Pilgrim. Spiritual Pluralism Along the Camino Finisterre and the Urge for the End," in Heritage, Pilgrimage and the Camino to Finisterre. Walking to the End of the World, ed. Cristina Sánchez-Carretero (Springer, GeoJournal Library 117, 2015), 175-211, https://doi.org/10.1007/978-3-319-20212-9_8. Marion Bowman and Tiina Sepp, "Caminoisation and Cathedrals: Replication, the Heritagisation of Religion, and the Spiritualisation of Heritage," Religion 49, no. 1 (2019): 74-98, https://doi.org/10.1080/0048721X.2018.1515325. Thorsten Wettich, "'Luther was here': The Making of Lutherweg as a Spiritual and Commemorative Pilgrimage," Journal of the Irish Society for the Academic Study of Religions (in preparation, 2020). Stausberg, Religion, 61. Sánchez-Carretero, Heritage, 96. 
spiritually or physically anymore. Even a pilgrimage dating back several centuries, such as El Camino, might become polyspiritual, attracting religious pilgrims, spiritual seekers, and non-believer tourists at the same time. That is primarily because the main elements of pilgrimage, such as retreat, silence, and personal contact with the transcendent, are an integral part of contemporary spiritual and esoteric movements, ${ }^{8}$ and also, inevitable kinship can be traced in the structure of tourism and pilgrimage. As Paul Post mentioned, the popularity can be explained by the fact that "the journey is an open ritual form that can be filled in by a varied group of pilgrims however they wish. It can be viewed as a quest for meaning, as a religious undertaking, as a sports achievement, as therapy and a way of coping after a crisis, divorce, mid-life crisis, or as an intense experience of nature, art, culture, and the past." ${ }^{\prime}$ It was already the Turners who mentioned that a "tourist is half a pilgrim, if the pilgrim is half a tourist." ${ }^{10}$ In many cases, spiritual tourism destinations build on a traditional pilgrimage site with a history of up to several centuries and add new layers of meaning. But "non-religious" and spiritual seekers, aiming to explore themselves better, also embark on "secular" pilgrimages. ${ }^{11}$ In addition to all this, the venues of historical events, the former residence and tombs of popular politicians, writers, athletes, and celebrities are also becoming popular destinations. ${ }^{12}$

8 Adrian Ivakhiv, "Nature and Self in New Age Pilgrimage," Culture and Religion 4, no. 1 (2003): 93-118, https://doi.org/10.1080/01438300302812. Kathryn Rountree, "Journeys to the Goddess: Pilgrimage and Tourism in the New Age," in On the Road to Being There: Studies in Pilgrimage and Tourism in Late Modernity, ed. William H. Swatos (Leiden: Brill, 2006): 33-60. István Povedák, "From Attila to the Hearth Chakra: Postmodern Pilgrimages," Acta Ethnographica Hungarica 59 no. 2 (2014): 371-388, https://doi.org/10.1556/AEthn.2013.001. István Povedák "A Pan-Hungarian 'Vessel Ritual' in Romania," in Politics, Feasts, Festivals, eds. Gábor Barna and István Povedák (Szeged: MTA-SZTE Vallási Kultúrakutató Csoport, 2014), 121-135.

9 Paul Post, Philip Nel, and Walter van Beek, "Introduction," in Contested Identities: Space and Ritual Dynamics in Europe and Africa, eds. Paul Post, Philip Nel, and Walter van Beek (Trenton: Africa World Press), 6.

10 Victor Turner and Edith Turner, Image and Pilgrimage in Christian Culture: Anthropological Approaches (New York: Columbia University Press, 1978): 20.

11 Peter Jan Margry, "Secular Pilgrimage: A Contradiction in Terms?" in Shrines and Pilgrimage in the Modern World: New Itineraries into the Sacred, ed. Peter Jan Margry (Amsterdam: Amsterdam University Press, 2008): 13-46.

12 For the overall analysis on these see Peter Jan Margry, ed., Shrines and Pilgrimage in the Modern World: New Itineraries into the Sacred (Amsterdam: Amsterdam University Press, 2008), https:// doi.org/10.5117/9789089640116. 
40 | "Give me some beautiful holy images that are colorful, play music, and flash!"

The Roma Pilgrimage to Csatka, Hungary

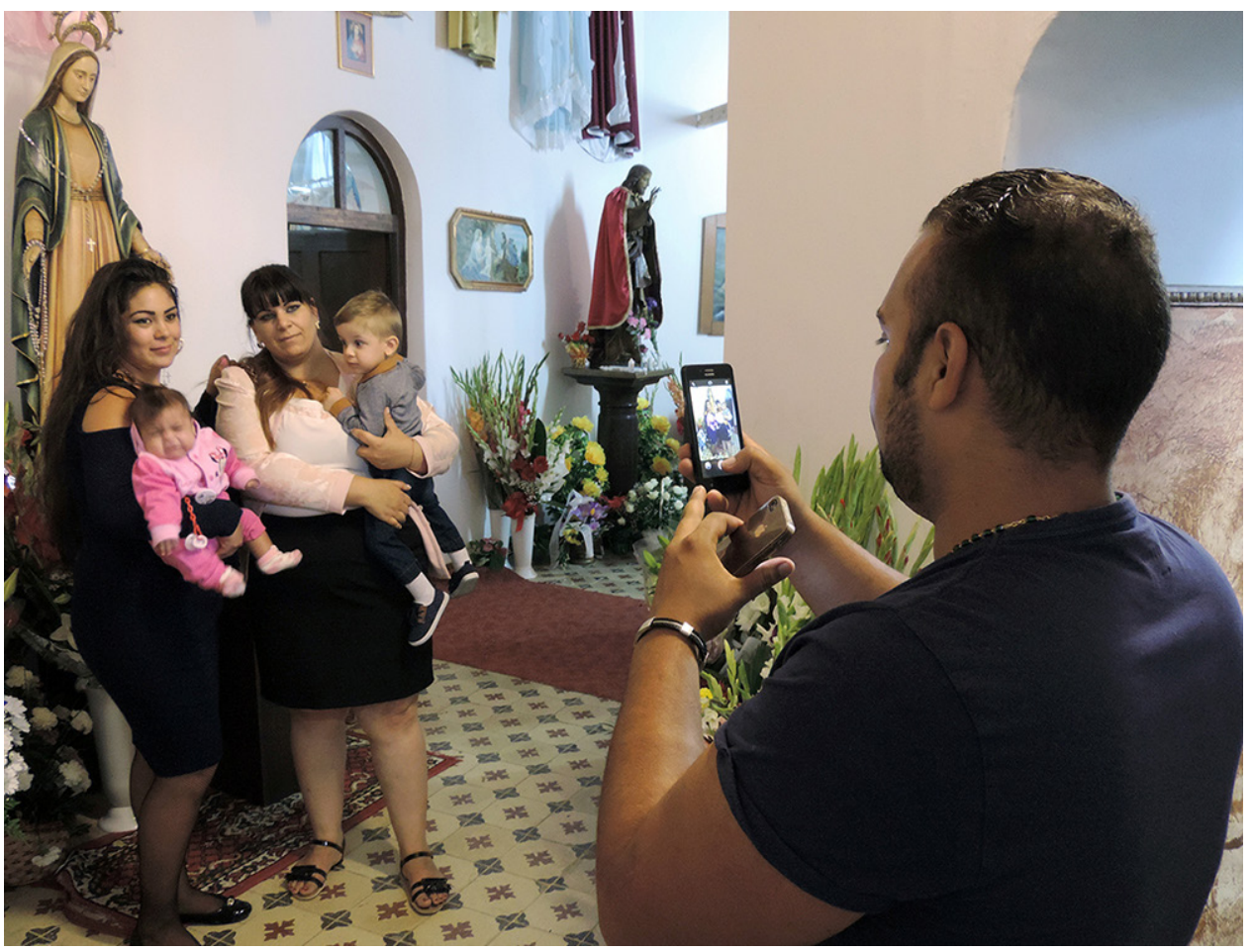

Pilgrims pose for pictures before the Virgin in the church in the valley. Photo by István Povedák, 2017.
The pilgrimage of Csatka to be presented in this study also carries traditional religious and secular ethnic features at the same time, but it acquired its present syncretic form in a different way. The pilgrimage site that appeared at the end of the 19th century - at the time of the apparitions in Lourdes—suddenly became popular in Hungary, attracting Hungarians, Slovaks, Germans and Roma at the same time. As a result of the historical changes, first the Slovaks and then the Germans disappeared, and by today, the always quiet and abandoned forest chapel of Csatka, a previously multi-ethnic pilgrimage site, becomes the "capital" of the Roma once a year. Roma come from all parts of Hungary, but also from Slovakia and Transylvania to the "Virgin Mary of Csatka," to the-as often referred by pilgrims- "Gypsy Csíksomlyó," in order to drink from the miraculous water of the forest spring, to wash their faces in the water, or to take some home for those who were not able to come. ${ }^{13}$ While the social influence of the Catholic Church in Hungary has been gradually weakening since the communist takeover in 1947 with a steady decline in Mass attendance and the number of those who profess to be religious, the

13 Presumably after the First World War, when Hungary lost its territory inhabited by Slovaks, and as a result of German deportations after the Second World War, only Hungarians and Gypsies remained who could attend the pilgrimage. Csíksomlyó [Şumuleu Ciuc in Romanian] is the most popular pan-Hungarian pilgrimage place in Transylvania, Romania. Despite the fact that Csíksomlyó is located roughly 400 miles from the Hungarian border, hundreds of thousands of pilgrims come from Hungary for the Pentecostal Mass every year. Today, Csíksomlyó has become one of the most important sacral centers of Hungarians, which represents the unity of the Hungarian nation torn apart by the Trianon Peace Treaty (June 4, 1920). 
popularity of the Csatka pilgrimage remains strong. This study presents the Roma pilgrimage to Csatka. In addition to the general introduction, the research seeks to answer two main questions: a) why the previously local pilgrimage of the isolated small settlement became the most important ritual of the Roma in Central and Eastern Europe; and b) what new, not necessarily religious traditions are unfolding in addition to (or instead of) traditional religious rites and actions? Throughout the paper I argue that the forest near Csatka-where non-religious rituals occur-is a special place not only in terms of Roma religious identity but also in terms of Roma ethnic identity.

\section{THE HISTORY OF THE CSATKA PILGRIMAGE}

If we want to introduce the brief history of the Csatka pilgrimage-apart from discovering the constant presence of the Roma as a curiosity or an exotic-we will not find any extraordinary event that would make us stand out from the 19thcentury pilgrimage sites. This, like all other places of pilgrimage, was made a place of worship by the people as a result of a grassroots movement. The spring water believed to be healing in the valley, the Virgin Mary apparitions, the crowd suddenly drifting there waiting for a miracle, and the doubts of the church office all are typical. ${ }^{14}$ Facts, sure knowledge, vague details, and legends intertwine in the case of the Csatka pilgrimage as well. On the one hand, the formation of the modern pilgrimage is accurately recorded by day. The historical sources- the work of the cantor and teacher of the village, and the report of the parish priest of Csatka to the bishop of Veszprém-precisely describe the beginnings. According to these, on August 21, 1862, in the afternoon Archangel Gabriel appeared to the hermit József Csöbönyei who lived in a cave dug by his own hand next to the spring in the wooded-hilly valley and informed him that the Virgin Mary would appear at the spring the next morning. Upon hearing the news, the people of the village, led by the cantor, marched from the church in Csatka to the well in the woods at 8 o'clock in the morning, where the hermit was kneeling waiting for them. After a short singing and prayer, three human shadows appeared, with a yellowish crown

14 For more details see János Bárth, "A Katolikus magyarság vallásos életének néprajza," in Magyar Néprajz. VII. Folklór 3. Népszokás, Néphit, Népi Vallásosság, ed. Attila Paládi-Kovács (Budapest: Akadémiai Kiadó, 1990), 371. 
42 "Give me some beautiful holy images that are colorful, play music, and flash!"

The Roma Pilgrimage to Csatka, Hungary

on the middle head, and then smoke rose from the ground. Those standing nearby not only saw the shadows and the smoke, but also smelled heavenly scent. ${ }^{15}$ Spontaneous pilgrimages then began immediately, first from the surrounding settlements and then from the wider region. Religious popular devotional literature telling the miracle of Csatka, published almost immediately in thousands of copies in Hungarian and German, are well known. The long-rejected, ambivalent attitude of the Catholic Church can also be well traced. ${ }^{16}$ In the absence of an official resolution, pilgrimages were initially banned and attempts were made to prevent the printing of books, however, the bishop of Veszprém, seeing the determination of the local faithful, authorized the construction of a chapel next to the well in 1863, which was consecrated on September 8, 1864. Several episcopal circulars were issued against the pilgrimage in Csatka, highlighting the "scandalous abuses" that took place there, and emphasizing again and again that "there is no shrine fortified and recognized as such in Csatka, but only a simple chapel in honor of the Blessed Virgin Mary." ${ }^{\prime 17}$ It was not until 1962, at the centenary of the vision of the hermit Csöbönyei, that Csatka received the officially approved pilgrimage place title from the bishop of Veszprém. In addition to historical events, the names of the hermits living next to the holy well since 1862, the architectural design of the place, the expansion of the chapel, the makers of the sculptures and frescoes and the time of their making are also known. ${ }^{18}$

Besides, more data is unknown and surrounded by legends. It is true that the hermit Csöbönyei dug a cave with a church permit in 1861 next to a well that had long been considered miraculous, but the memory of the previous healings is preserved

15 The events and the subsequent visions and miraculous healings were recorded by the cantor of the village. See Márton Takáts, A csatkai szent kut és kápolna eredete, s az ott történt csodák és látványosságok hü leirása (Gyôr: Sauervein Géza, n.d. [1862]. The minutes of church examinations are published in Gyula Perger, "A hívő nép és a kételkedő egyház. A csatkai csoda egyházi vizsgálatai," in Liturgikus Örökségünk 21, ed. Iváncsó István (Nyíregyháza: Görög Katolikus Hittudományi Főiskola, 2017), 189-238.

16 See Perger, A hívö, 192-211.

17 The circular letter of the Bishop of Györ on October 10, 1911. Litterae Circulares Venerabilem Clerum Almae Diocesis Jauriensis (Győr, 1911).

18 Most of them were faithful believer laymen who lived ascetic life. 
by only a few obscure legends. ${ }^{19}$ We also have incomplete data on the changes that took place during communism and socialism. The communist state authorities did not ban the pilgrimage but tried to strengthen the profane part, the entertainment, instead of the sacred one. At that time, the proliferation of chain swings, target shooting, alcohol counters, and the strengthening of secular entertainment was generally observed at the pilgrimage sites. Attempts were made to trivialize, "enchant" the actors and events associated with the place, with articles published in the press. However, the popularity of the Csatka pilgrimage remained unbroken. In 1941 - two months after Hungary entered World War II — tens of thousands of pilgrims have been reported, and a crowd approximately of the same size can be seen in the famous scene of the 1966 movie How the Trees Run which authentically represented that year's Csatka pilgrimage. ${ }^{20}$ Twenty thousand pilgrims in 1972 and eighty thousand in 1979 (probably exaggerated) were reported by the local paper, and even today the number of pilgrims is estimated at 10-15,000, far beyond the number of pilgrims and religious tourists arriving at most pilgrimage sites in Hungary. ${ }^{21} \mathrm{How}-$ ever, we do not know exactly how long the Roma have been present in Csatka, and when and why the pilgrimage became dominantly a Roma, ethnic ritual.

\section{ROMA AT THE CSATKA PILGRIMAGE}

The first precise, ethnographic description of the pilgrimage of Csatka was given in 1940 by the well-known Hungarian ethnographer of the time, Aurél Vajkai. In a study published in the columns of the journal Ethnographia, he had already

19 It is said that in 1792 a blind man named Vilmos Meizler was healed here. Aurél Vajkai, as well as the "Minutes of the Csatka Investigation," dated 1865 (See Perger, A hivö, 221-222.), noted that the parish priest of the neighboring Súr had been watching pilgrims and miraculous healings for 26 years. "He has been watching this place since 1837 and says many patients have come here who drank from the water, washed their painful limbs and knelt in front of pictures hanging on tall beech trees." See Aurél Vajkai, "A csatkai búcsú. Adatok a népi orvosláshoz," Ethnographia 51, no. 1 (1940): 51.

20 Márta Pereszlényi, "Adatok a csatkai búcsúhoz," Ethnographia 50, no. 1 (1941): 284-285. Pál Zolnay's film How the Trees Run was released in 1966. Its most famous scene depicts the protagonist in a mass of ten of thousands in the Csatka pilgrimage. The interesting thing about the scene is that it was not recorded in advance, but spontaneously, improvised between the pilgrims, which makes it of outstanding documentary value to us.

21 Zoltán Györke, "Csatka igazi arca," Dolgozók Lapja (April 8, 1972): 4. The newspaper's correspondent reported 15,000 cars and 5-600 buses in the 300-resident settlement. See Vilmos Wér, "A csatkai búcsún," Dolgozók Lapja (September 16, 1979): 7. 
44 | "Give me some beautiful holy images that are colorful, play music, and flash!"

The Roma Pilgrimage to Csatka, Hungary

reported that Roma had always been present at the event since the pilgrimages began. According to Vajkai, "the most striking colors for the already vivid image of the ritual are given by the insatiable gypsies gathered there [...] Ever since they held a pilgrimage in Csatka, the gypsies have always been here. Here, the Gypsies of Transdanubia meet, get to know each other, discuss their affairs, hold gypsy engagements (including four or five) once a year." 22 However, he did not mention either why the pilgrimage became the most important ritual of the year for the Hungarian Oláh Roma, making the isolated, depopulated small settlement the "capital of the Gypsies" once a year. Asking among the pilgrims about the origin of the Roma pilgrimage, we were able to record several legends and guesses. On the one hand, as a folklorized version of historical events, it is widespread among Roma that the first miraculous healing at the source actually happened to a Roma man. That is, Csatka was originally a sacred place and rite connected with the Roma. Therefore, this story adds to the significance of the place in particular, as Roma basically have little or no sacred places associated with Catholicism. ${ }^{23}$ The forest near Csatka is therefore a special place not only in terms of their religious identity but also in terms of their ethnic identity. "By 1862, there was a gypsy boy who had been blind since his childhood. He came, drank from the spring water, and was healed. He was the friend of the Count's son. And he built it in 1863 and patented this place. And so it became a very big, famous shrine to weep our sorrows here, and our joy $[\ldots]$ And then they came here and they call it gypsy pilgrimage, because it's about the gypsy boy, it's about a blind gypsy child, about an eighteen-year-old boy and that is why this shrine became famous." (54-year-old-woman from Pápa ${ }^{24}$

Others suspect the symbolic return of the ancient, nomadic way of life behind the presence of the Roma. The proximity of nature, camping in the woods, making music and reveling with family members and friends around the campfire really allow them to relive nomad traditions and tribal-ethnic frameworks. "Csatka is so in the woods, they make fires as if they were camping. It has become an ancient

22 Vajkai, A csatkai, 63.

23 The most important pan-Roma pilgrimage site is Saintes-Maries-de-la Mer in France that was built on the cult of St.Sarah.

24 Mogyorósi heard a different version of this, in which Mary appeared to an Oláh Gypsy woman. See Mogyorósi Ágnes, "A csatkai cigánybúcsú," Erdélyi Múzeum 76, no. 1 (2014): 66. 


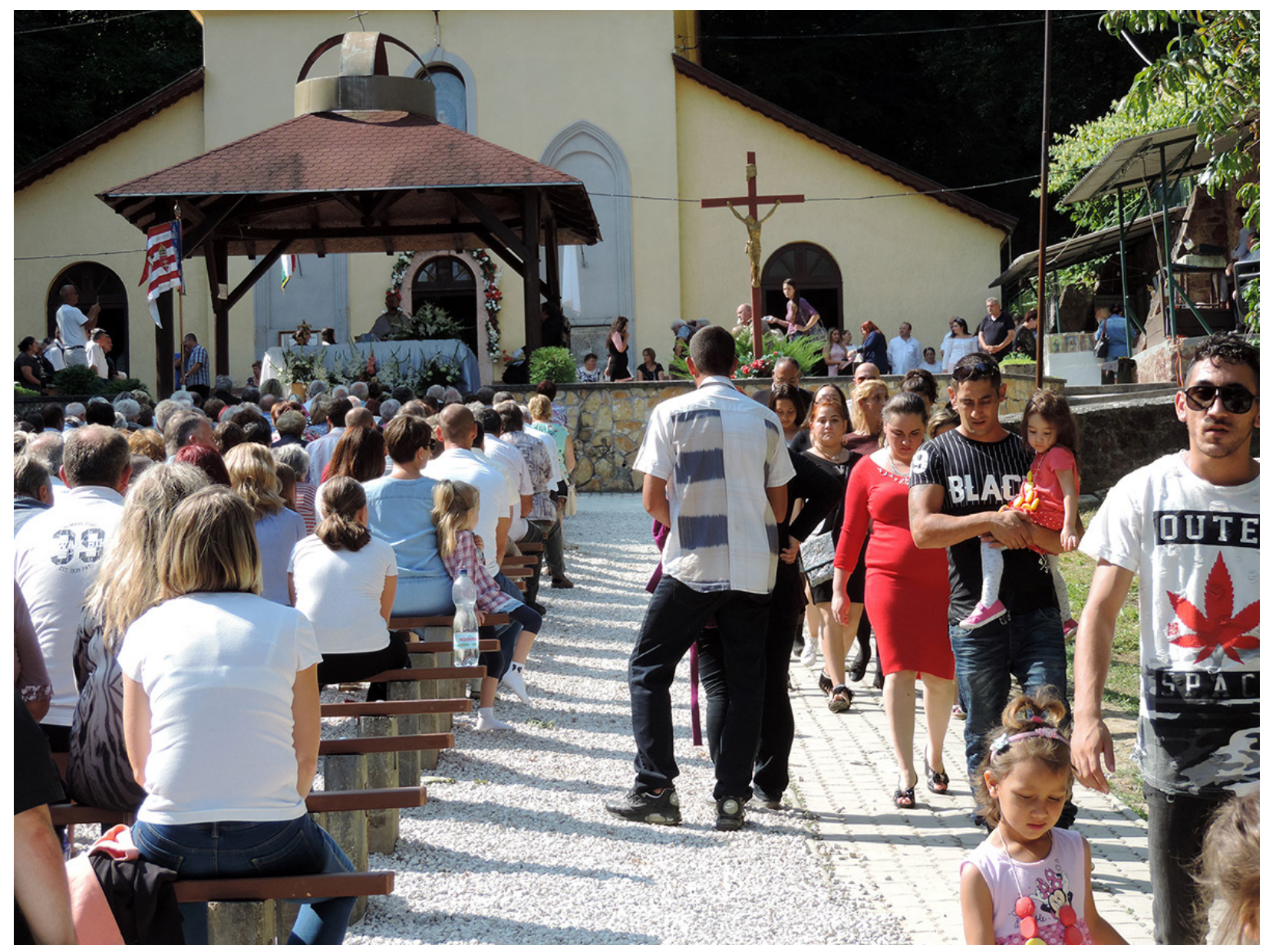

tradition for them to come here for several generations. Their ancestors also camped in forests, setting fire. Here, even in the 'cursed years,' the party was allowed in the evenings, not at any other pilgrimage site.” (50-year-old-man from Pápa ${ }^{25}$

Holy Mass celebrated by the bishop of Veszprém. Photo by István Povedák, 2017.

Bishop János Székely, the emblematic figure of the Hungarian Catholic Church's pastoral mission to the Roma, considers it especially important that during pilgrimages Roma relive and experience the freedom of their former nomadic way of life and the closeness to nature. ${ }^{26}$ Therefore, the fact that the participation of Roma at the pilgrimage of Csatka on September 8 is more significant and important than any other pilgrimage in Hungary is presumably not only the consequence of its religious nature. It is conceivable that in the middle of the 19th century, when visions, Marian apparitions, and pilgrimages abruptly multiplied, miraculous healings actually took place with Roma in Csatka encouraging them to participate. Like the Germans, Slovaks, Hungarians, the Roma were also able to get involved thanks to this Durkheimian "collective effervescence." It is very likely that in the second

25 "Cursed years" refers to the Communist era in public speech in Hungary.

26 János Székely, Cigány népismeret. Te del o Del baxt! (Budapest: Szent István Társulat, 2010): 76. 
46 | "Give me some beautiful holy images that are colorful, play music, and flash!"

The Roma Pilgrimage to Csatka, Hungary

half of the 19th century, the Roma who were still nomadic appeared at the same time as Roma who were already settled but thought of migration as an ancient tradition, with nostalgia. And the pilgrimage, in addition to being a religious rite, could also provide a good disguise for otherwise unauthorized Roma gatherings, fairs, revelations, and marriage rites held according to ancient Roma customs. ${ }^{27}$ Several official sources even from 1938 prove that the authorities were in trouble with a huge crowd of Roma arriving for the pilgrimage, so they tried to keep them out of the rite by force, because, as they write, "Gypsies appeared en masse with an official permit, partly with their own car, partly with the help of transporters, and scandalous rites were held there under the guise of performing spiritual exercises. This gathering is mostly used by the gypsies to get young gypsy bachelors to get acquainted with the gypsy girls, to commit wild marriages [...] to steal, rob and commit bodily offenses on the way [...] special care should be taken to ensure that the stray gypsies or other stray groups cannot get even to the close vicinity of the place. ${ }^{28}$ In her study, Mogyorósi provides a different explanation. According to this, the pilgrimage in Csatka was a pilgrimage of the poor, which meant that pilgrims belonged to the lower social strata. Because of this, the Roma were not stigmatized, did not feel like outsiders, and were not discriminated by other pilgrims of Gadjo origin. ${ }^{29}$ However, this assumption does not explain why in other pilgrimage sites, which were also attended by the poor and- to a lesser extentRoma, a similar process did not take place and why only Csatka became a Roma pilgrimage site and even "the" Roma pilgrimage site they have been visiting for generations. Furthermore, historical sources also attest to the fact that the Roma and the Gadjos always celebrated the pilgrimage separately and in different ways. In 1940, Vajkai was clearly saying that Hungarians, Germans, and Slovaks had settled in one part of the meadow next to the forest, while Roma were camping at the

27 Since the Middle Ages, the Hungarian authorities have had problems with the fact that the Roma people, especially the Oláh Gypsies, insisted on their own tribal legislation. Roma legislation, i.e. Romani Kris, did not operate on the basis of state laws, which is why such gatherings of Roma were forbidden since the reign of Queen Maria Theresa (1740-1780). Similarly, marriages held in the forests, according to ancient Roma custom, were also forbidden. See more Kamill Erdős, "Cigány törvényszék. Romani-Kris" Néprajzi Közlemények 4, no. 1-2 (1959): 203-215.

28 Decree of the vice-comes of Szombathely from January 1938. See Vasvármegye Hivatalos Lapja, (Szombathely, 1938): 5-6.

29 Mogyorósi, A csatkai, 66. 
other end. Moreover, from today's point of view, he expressed his opinion rudely and intolerantly for a folklorist, saying that "Five hundred or a thousand gypsies are shouting, flashily colored foreign bodies in a unified crowd of ten thousand." 30 Separation, segregation and the lack of common celebration was perceptible even then, and it is no different today.

Roma and Gadjo pilgrims are still separated today, and even have different attitudes toward certain places and rites of pilgrimage. This can be observed in their behavior on the pilgrimage site, in the use of space, and of religious rites. Unlike "traditional" Gadjo pilgrims a Roma pilgrim does not arrive in a community of devotees with flags singing traditional religious hymns. Although some Roma organizations and religious communities organize bus rides, most Roma today arrive by car and with family. Many come in convoys and settle in the meadow on the hilltop with their children, parents and grandparents, and set up tents. Usually they arrive on Saturday morning, but there are several who arrive a day earlier: "Already on Friday, and they bring the two cauldrons [for cooking outside]. The Roma political leader [voivode] also comes from Orosháza and is waiting for friends and relatives." (50-year-old-man, Pápa $)^{31}$

Upon arrival, their first stop is the tents of the merchants set up along the road from the car park to the valley, where they purchase the candles and the Virgin Mary-shaped holy water containers. Then they visit the Chapel of John Paul II, the so-called "Gypsy chapel" that was built for the crucifix made of cherry wood, taken in 2003 by Roma pilgrims to Rome, and blessed by Pope John Paul II. ${ }^{32}$ The cross was made at the request of the National Minority Gypsy Self-Government by István Hegedűs, a gypsy woodcarver, who also modeled the corpus on

30 Vajkai, A csatkai, 63.

31 Orosháza is at the opposite end of the country.

32 Mogyorósi notes that the chapel was built for the Gypsies by the National Gypsy Self-Government. From a liturgical point of view, however, it does not fulfill the original function intended for it. There is no altar in the chapel, only in the middle of the crucifix, behind it are pictures of John Paul II and the Virgin Mary, while around the walls are photographs of a visit to the Pope with prominent figures of the National Gypsy Self-Government. Mogyorósi, A csatkai, 58-59. 
48 | "Give me some beautiful holy images that are colorful, play music, and flash!"

The Roma Pilgrimage to Csatka, Hungary
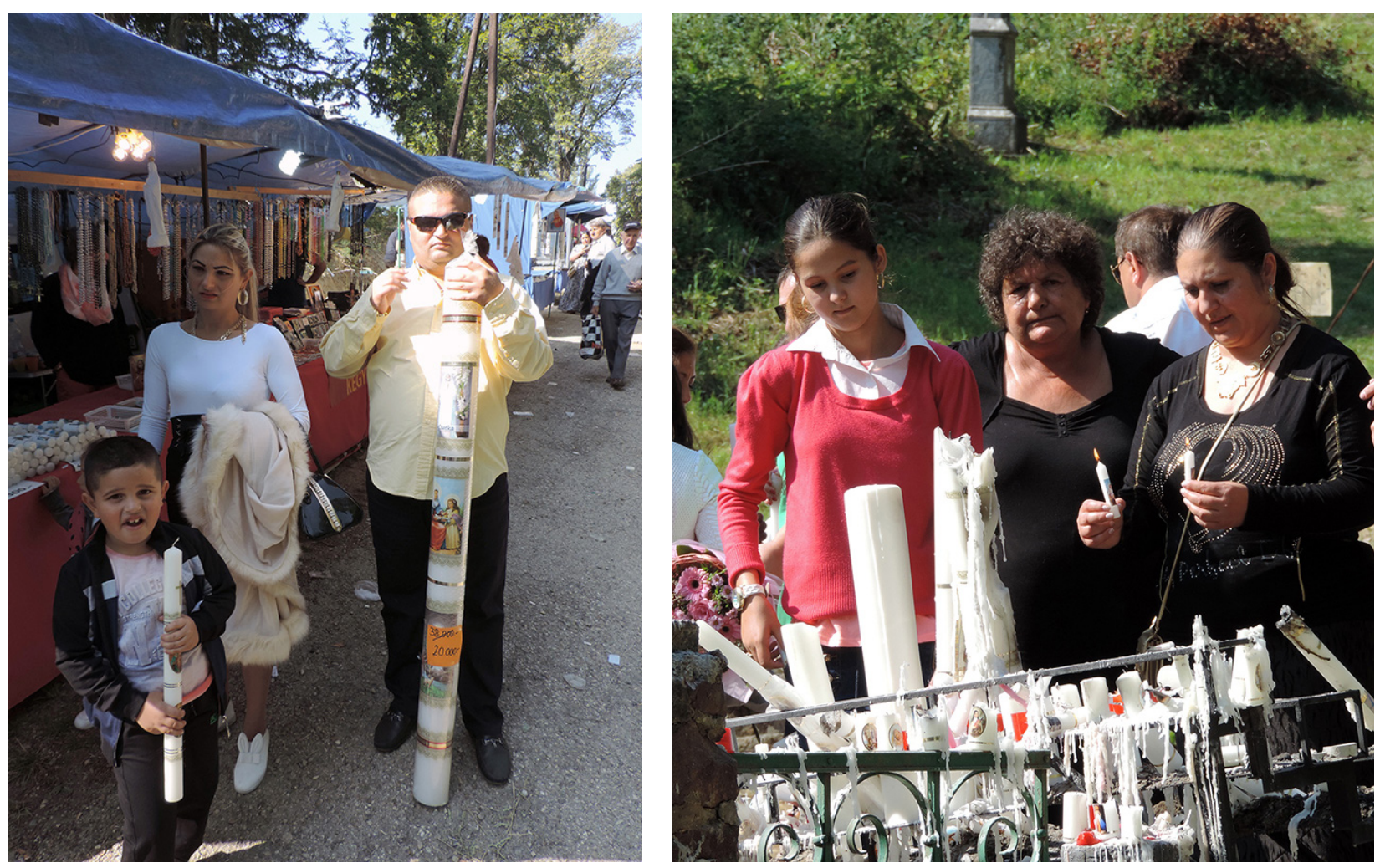

Pilgrims buy candles to light in front of the chapel. Photos by István Povedák, 2017 the cross from a Roma man. ${ }^{33}$ The inscription in Lovari is "Szuntona Dévla Zsutin E Romen" (Holy God, help the Roma). The Roma pilgrims who come here light the candles - an obligatory supply — here in front of the chapel. Each member of the family also lights one or more candles. Children light a smaller, adults a larger candle often weighing several pounds and one and a half meters high. As a result, the melted wax from the constantly growing candles flows down the hillside like white lava after a few hours. When they enter the chapel, the first thing they do is photograph the cross and then themselves. The younger ones post the pictures instantly on Facebook and Instagram. Many begin praying spectacularly in front of the "candle forest" around the outdoor statue of the Virgin Mary. Then the next stop is the church in the valley, where the women place new bouquets of flowers and vases in front of the altar, throw money in the moneybox, and then take family photos. Many of them start petitioning the Virgin Mary: "What I really like is that Gypsies always kneel in front of the altar and pray to it in Gypsy language and it's so beautiful. They take the little children down to sanctify, to bless [the Virgin].” (55-year-old-woman, Zalaegerszeg)

33 According to the Hungarian legal system minorities have the right to form local and national self-governments. The minority self-governments have the authority to maintain institutions in the areas of education and promotion of traditions and culture, as well as to establish minority media. 


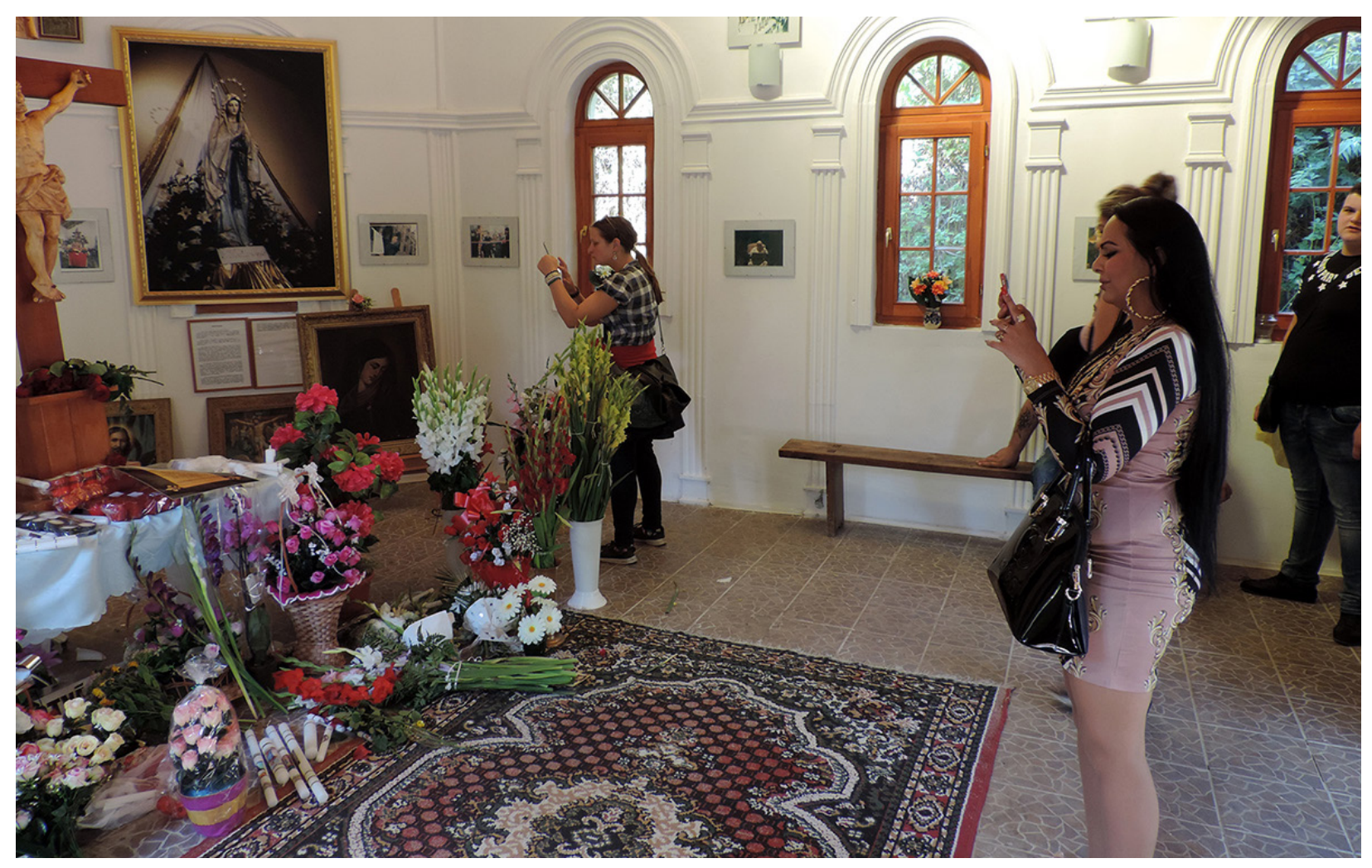

For most of the Roma, participating at the pilgrimage is the only voluntary liturgical action during the year beyond which they do not enter the church gates. As a couple in their 60s from Kalocsa said, "We are Catholics. We don't shy away from the church. If there is something, we go. For example, if we have marriage or baptism." Therefore it is not a surprise that great number of Roma pilgrims do not behave according to the expectations customary in the liturgy. Especially group baptism of four to five or even more children in the church represents that a significant part of Roma pilgrims have different "Holy Mass culture" to Gadjos. Instead of silence, it is common to talk to each other, comment on events, enjoy the reactions of the child to be baptized and even chew gum, which could make the rite sometimes a bit chaotic for the priest as well.

In Csatka Roma do not take part in the open-air Masses, except for the Saturday evening Mass held in Lovari. If by chance the Mass is taking place, they neglect it and walk quietly next to the rows of benches to the holy well. The only exception is the Lovari Mass, in which a "poster group" of Catholic Roma pastoral mission usually provides guitarist church music with a Gypsy-ish atmosphere. The holy well is located behind the rows of benches, a few meters deeper. The elderly Roma pilgrims usually sit on the benches built around the well while their younger family members stand in rows to the water. When they get there, they drink, wash their
Roma take pictures in the "Gypsy chapel." Many younger pilgrims will post them on social media. Photo by István Povedák, 2017.

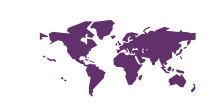

Catholics $थ$ Cultures 

The Roma Pilgrimage to Csatka, Hungary

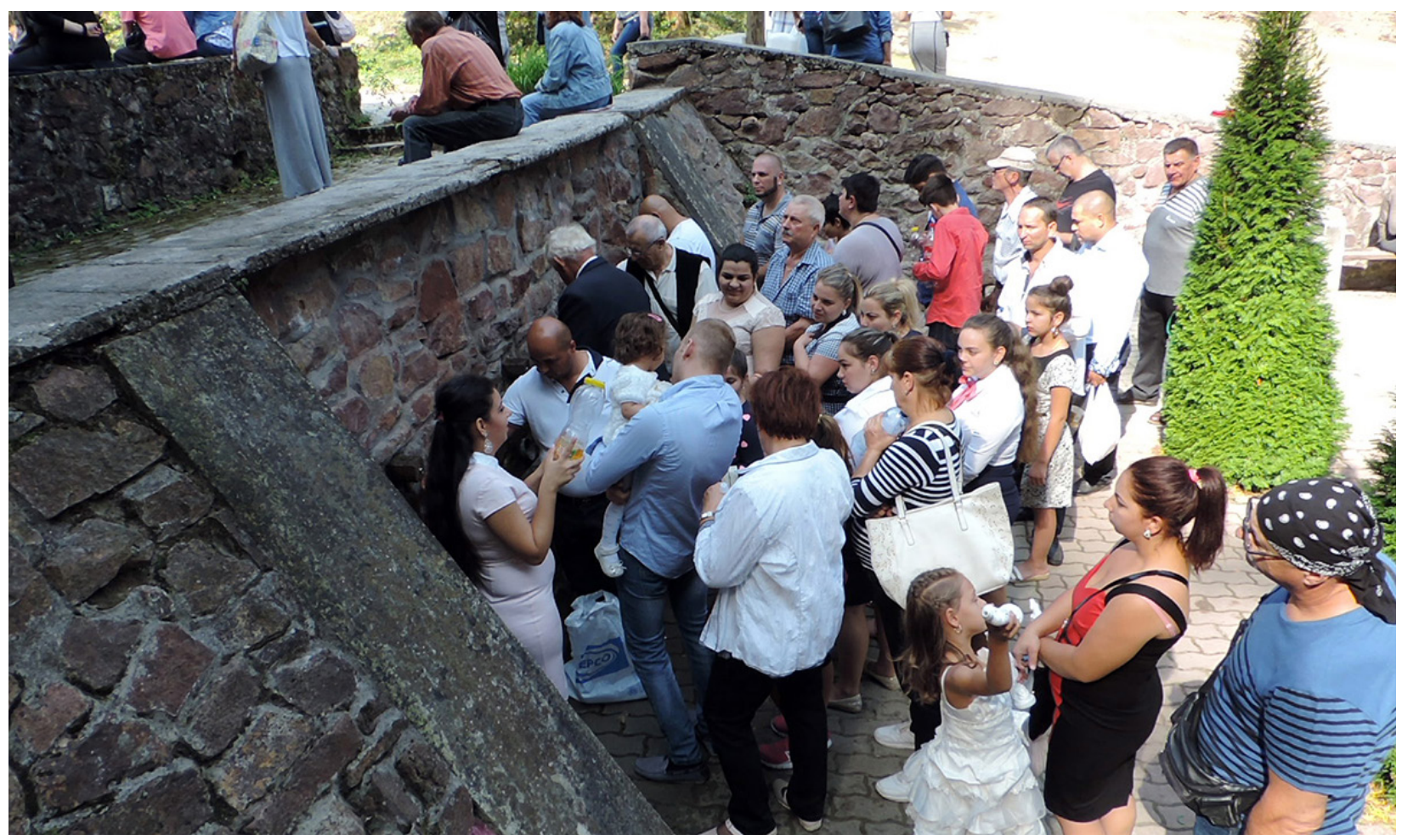

Visiting the holy well is one of the main motivations for pilgrims to Csatka. Photo by István Povedák, 2017. children's face and eyes with the water, and refill their bottles. In fact, visiting the Virgin Mary and taking in the water of the holy well are the two main motivations-of a religious nature-among the Roma pilgrims. As a 47-year-old man from Komárom, Slovakia said, "The first thing we did was come down to the well. We dedicate ourselves first. We apologize to Saint Mary and our dear Holy God. We consecrate the house at home and everything else. Car, house, ourselves." Similarly, a 54-year-old man from Györ mentioned: "There is water in the car here as well." And what do you do with that? "I consecrate the house, the children, my grandchildren, I wish good luck to my house, all which is inside, and if something bad hits the house, I sweep it all with it.”

But we also met an informant who did not consider himself a believer; still he did not question the miraculous power of the spring water of Csatka: "I do not believe in God, only in my own way, but in the Virgin Mother. I came on this pilgrimage to accompany my family. Everyone in my family is religious except me. I only come every year to take care of them. And so I can take miraculous water to heal from it. I believe in the power of the miraculous water. We always take it home with many big bottles so I can cure my strong migraine-like headaches." (54-year-old-man, Tapolca) For Roma pilgrims, visiting the holy well closes the series of sacral acts. Up from the well, they buy jewelry, ornaments, toys and clothes for the children, and then the secular fun begins on the meadow next to the parking lot in the forest. 


\section{THE SOCIAL DIVISION OF PILGRIMS AND THE REPRESENTATION OF HIERARCHY}

There is a buge tumult in front of the church, which does not diminish when you enter the building. Between the two rows of benches, a visibly wealthy Roma man in a white suit, holding a white hat in his hands, settles his large family. The women had already placed their own bouquets of flowers in the vases. Each huge bouquet of gladioli was clearly visible. The grandmother dressed for the celebration in front of the altar is holding her granddaughter, surrounded by her sons, her grandchildren without exception, all in suits, ties, buge gold rings on several fingers, heavy gold chains around their necks. Each of them puts their own wife and children up the stairs in front of the altar and tries to photograph them in the tumult with their smartphones, while the older man, who seems to be the head of the family, tries to set everyone up in front of the altar for a common picture. Because of the busy and crowded family, no one else can get close to the altar among the narrow rows of benches, but apparently they don't even want to go there. They wait patiently or walk away. The middle part of the church now belongs to the elegant family, as if the event was all about them. They are appropriated as if a wedding photo was taken at a family event. And for them, now maybe it really is. A family meeting held on a sacred site, on the occasion of a sacred rite.

Although Csatka is regularly called the largest Roma pilgrimage in Central Europe and the second largest in Europe, we cannot say that the event is a pilgrimage for all Roma. It is not like the usual one-week ceremony and cavalcade in SaintesMaries-de-la Mer, which lists almost all Roma clans from several European countries, but mainly Oláh Roma arrive from Hungary and Slovakia (to a lesser extent from Romania, Serbia). Thus, it is not the pilgrimage of all Roma, but it is popular mostly among the Oláh Roma, who still speak the Lovari (Roma) language and are the most active in preserving Roma traditions. There are significantly smaller numbers of Romungros (Hungarian Roma) who no longer speak the Roma language 
52 | "Give me some beautiful holy images that are colorful, play music, and flash!"

The Roma Pilgrimage to Csatka, Hungary

and don't preserve traditions. ${ }^{34}$ It is likely that the number of Romungros may have declined sharply during the years of the communist dictatorship, which did not prefer religiosity. In 1940, Vajkai even noticed that the Roma were not uniform and that the urban musician Roma present at the pilgrimage looked down on and didn't even talk to the silent, secluded, separate groups of Roma villagers, tinsmiths and Lovari speaking Oláh Roma who were dressed in simple gray rags. ${ }^{35}$ However, a 1961 report, referring to the Oláh Roma, already pointed out that "the Gypsies here have the strata that cling to the old way of life: the people who travel from village to village by horse-drawn carriage." ${ }^{36}$ All this, of course, were not even noticed by Gadjo participants for a long time, and the external, superficially judging "Gadjo gaze" is generally still unable to distinguish between the groups of Roma today. ${ }^{37}$

The social division of the Roma can also be clearly perceived during the pilgrimage. As we have seen, the poorest strata, for whom attending the feast is truly a sacrifice, have been present from the beginnings in the late 19th century. In 1940, Vajkai even remarked that "the humble kolompárs [referring to Oláh Roma] do not even bark, quietly crouching separately. Hungarians also prefer to see them than urban gypsies in loud, ornate clothes." ${ }^{38}$ As an elderly man put it, "We have little fun throughout the year, we just work and save. But if we come to Csatka, we will have a good time here. That's why we save all year so we can honor the Virgin Mary here." (Retired man from Slovakia)

The festive occasion is associated with shopping and spending money, even for the poorer Roma. The restraint of the ordinary and the festive roaring are sharply separated. While the poorer Gadjo pilgrims bring sandwiches with them, the Roma buy food and drink at the fair. Extensive spending of money can also be well

34 In Lovari (Romani) language, Romungro [Hungarian Roma] is called the most populous group of Roma in Hungary. Romungros, who make up roughly two-thirds of the Hungarian Roma, are more organically integrated into Hungarian society than the other Roma groups: they no longer speak Lovari language and do not wear traditional Roma clothing.

35 Vajkai, A csatkai, 63.

36 László Havasházi, "Ki esketett?" Dolgozók Lapja (September 16, 1961): 5.

37 It is worth noting at this point that the coexistence of Roma and Hungarians in recent centuries has created parallel societies in which the Hungarian majority has little knowledge of Roma cultures and their division.

38 Vajkai, A csatkai, 63. 


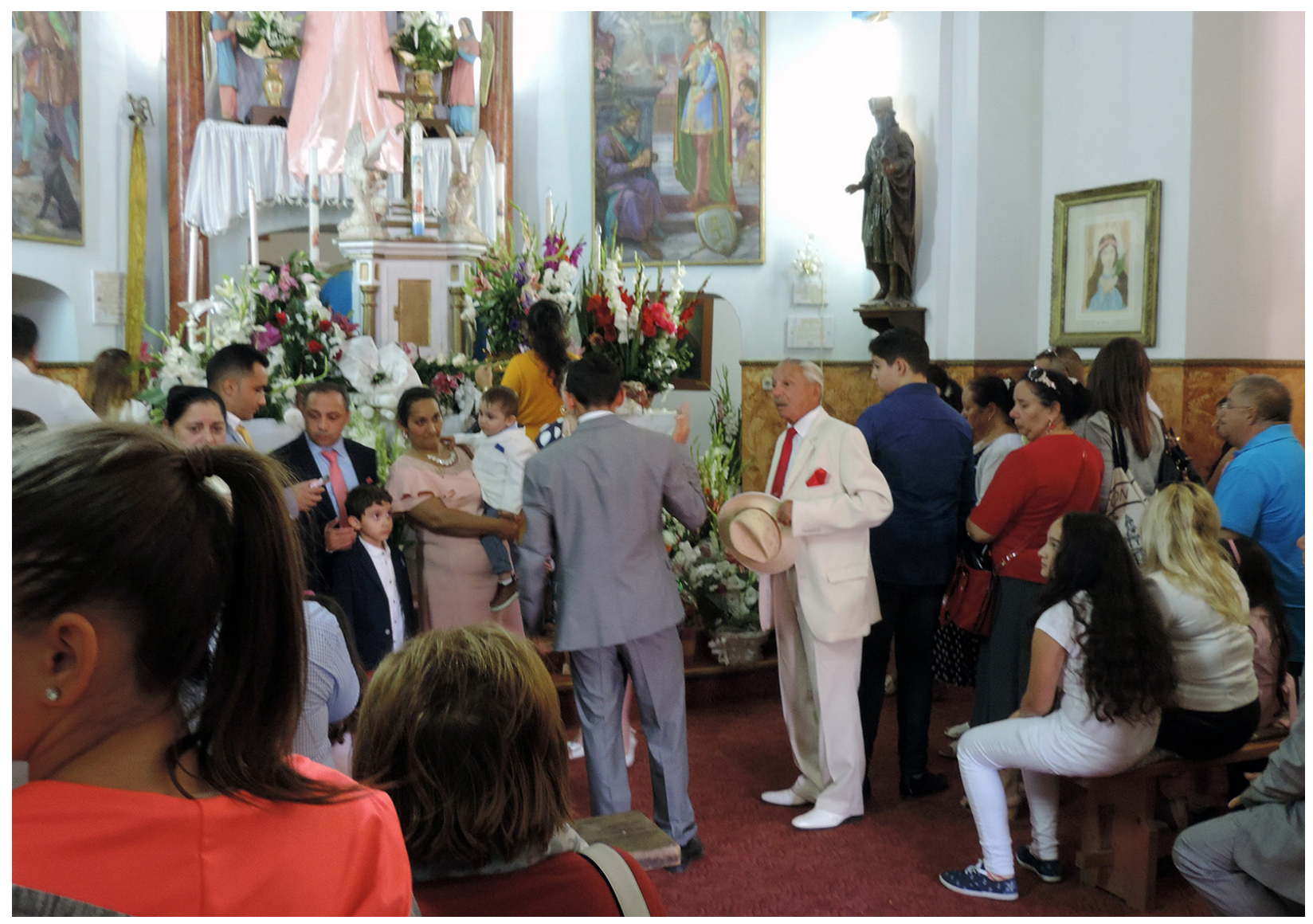

observed when buying gifts. As Szuhay pointed out, Roma interpret the requirement to spend money during the pilgrimage as obligatory; they must come with serious sums. It is a shame if someone eats from a bundle and doesn't have enough money to buy food and drink for themselves at the vendors. ${ }^{39}$ However, in addition to the poorer Roma pilgrims, there is also the Roma aristocracy, who are visibly separated from the others. The ornate attire, the jewelry, the larger and more expensive candles, the bouquets of flowers all are meant to represent their status. In the eyes of "outsider observers," especially for the perspective of "traditional" pilgrims, their exclusivity is often ambiguous and inconsistent with the values of the Catholic pilgrimage site. As a Gadjo pilgrim said, "You see not the crappy, poor Gypsy here, but gentlemen Gypsies full of goldenseal rings! Some are pulled by the chain around their neck, there is so much gold on it!" (59-year-old-man, Pápa)

It is common among wealthy Roma families to bring a porcelain vase of flowers and sew clothes for the statue of Our Lady in addition to the usual offers. Every year, five or six clothes made of silk, often with gold and pearls, are brought as a

39 Péter Szuhay, A magyarországi cigányság kultúrája: etnikus kultúra vagy a szegénység kultúrája? (Budapest: Panoráma, 1999), 114.
A well-dressed family poses for photos in the church. Photo by István Povedák, 2017. 
54 | "Give me some beautiful holy images that are colorful, play music, and flash!"

The Roma Pilgrimage to Csatka, Hungary

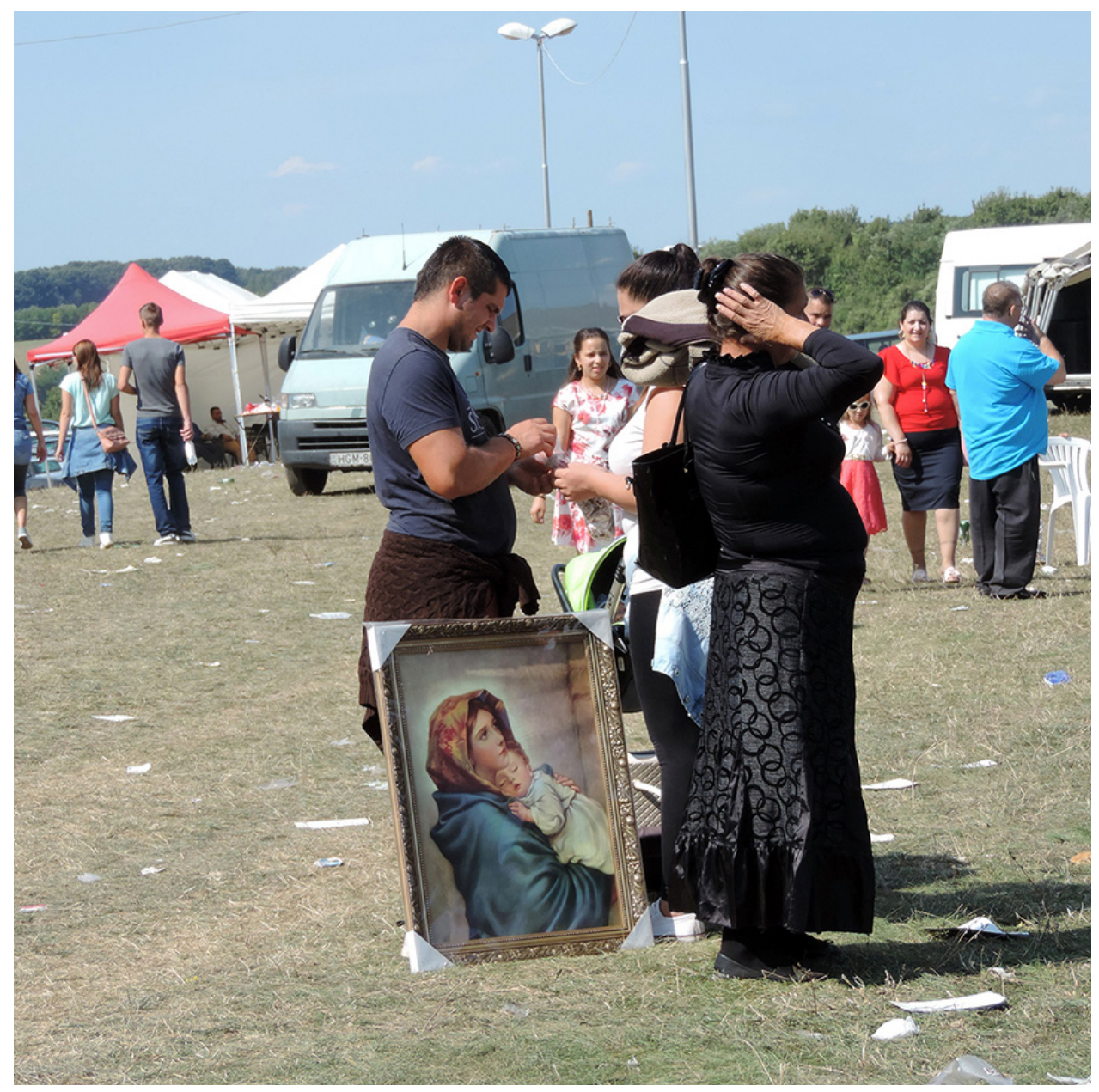

Shopping and spending money is part of the Roma experience. Photo by István Povedák 2017.

vow gift. As the giver expects the statue to be dressed in the clothes they donated, the statue must be redressed several times during the pilgrimage. In addition to material gifts, money thrown into the moneybox is also a status symbol, although one of the organizers reported a decrease. As he said, "They spend more now at the vendors up there than below at the church. There is a lot less money now, but that was not the case in the past." (50-year-old-man, Pápa) Others said that there was a family that had a crown made for the statue: "This statue of Mary, this shrine, the chapel were also built by the Gypsies, I know that, and the statue also has many gold jewels that the Gypsies made for her, she also has a golden crown." (41-yearold-woman, Szombathely)

The representation of social status with externalities is not a new feature, and naturally not only a Roma feature. The most expensive vehicle is a natural part of prosperity, which the Roma who come to the pilgrimage proudly emphasize without any modesty. In the 1930s, when the car was a gentleman's luxury in the countryside, Vajkai had written that a member of the Roma aristocracy from Pápa (a town 
$60 \mathrm{~km}$ from Csatka) traveled by car, to everyone's amazement, and today several people mentioned that there was an aristocrat who recently arrived in Csatka by private helicopter. ${ }^{40}$ Beyond these, the social hierarchy is well perceived not only in appearance but also in behavior. The rich Roma, the aristocrats, are separated from the "ordinary" Roma. They do not contact them; they do not communicate with them. When my Roma students in the research tried to interview members of the more moderate Roma family mentioned in the introduction, they were unsuccessful. They either looked through them, not answering them, or sent them away. As Gadjo researchers, we might think that this kind of segregation generates negative feelings in ordinary Roma, but that is not what happens. The situation is natural for both members of the Roma aristocracy and the rest of the Roma pilgrims. It can be felt that the Roma pilgrimage for the aristocrats is not about meeting all the Roma, but about meeting their own social "caste," their relatives, friends, other voivodes and their families. At the same time, their presence is natural or even positive for other Roma, who find no objection to the expressive emphasis on luxury, as they all pay a special attention to their appearance, their festive attire, so that everyone can see their jewelry. ${ }^{41}$ Aristocrats are not contemptuous of other Roma, and similarly, the average Roma are not envious seeing aristocrats dining separately. Moreover, the aristocratic Roma's adherence to traditions and participation in the Roma pilgrimage show their adherence to ethnic identity. Later in the evening when the party has already started up in the meadow, social differences might even fade in direct proportion to the intensity of nighttime revelry and the amount of alcohol consumed. ${ }^{42}$

\section{SACRED AND PROFANE, PARTY AND ROMA IDENTITY}

Concerning the structure of pilgrimage place, Post emphasizes that " $[t]$ here is no longer one center, one cultural zone, such as institutional religion, that is

40 Vajkai, A csatkai, 63. The Neo-Rococo Gypsy palaces built in several Romanian settlements-mainly in and around Bánffyhunyad-also serve to boast of the financial situation.

41 According to Szuhay, whom I do not completely agree with, the presentation of wealth is not directed at the poorer Roma either, but they want to show their success to the Gadjos and expect recognition from them. See Péter Szuhay, Sosemlesz Cigányország (Budapest: Osiris, 2012): 55.

42 Leonard Norman Primiano, "Vernacular religion and the search for method in religious folklife," Western Folklore 54, no.1 (1994): 37-56. 
56 | "Give me some beautiful holy images that are colorful, play music, and flash!"

The Roma Pilgrimage to Csatka, Hungary

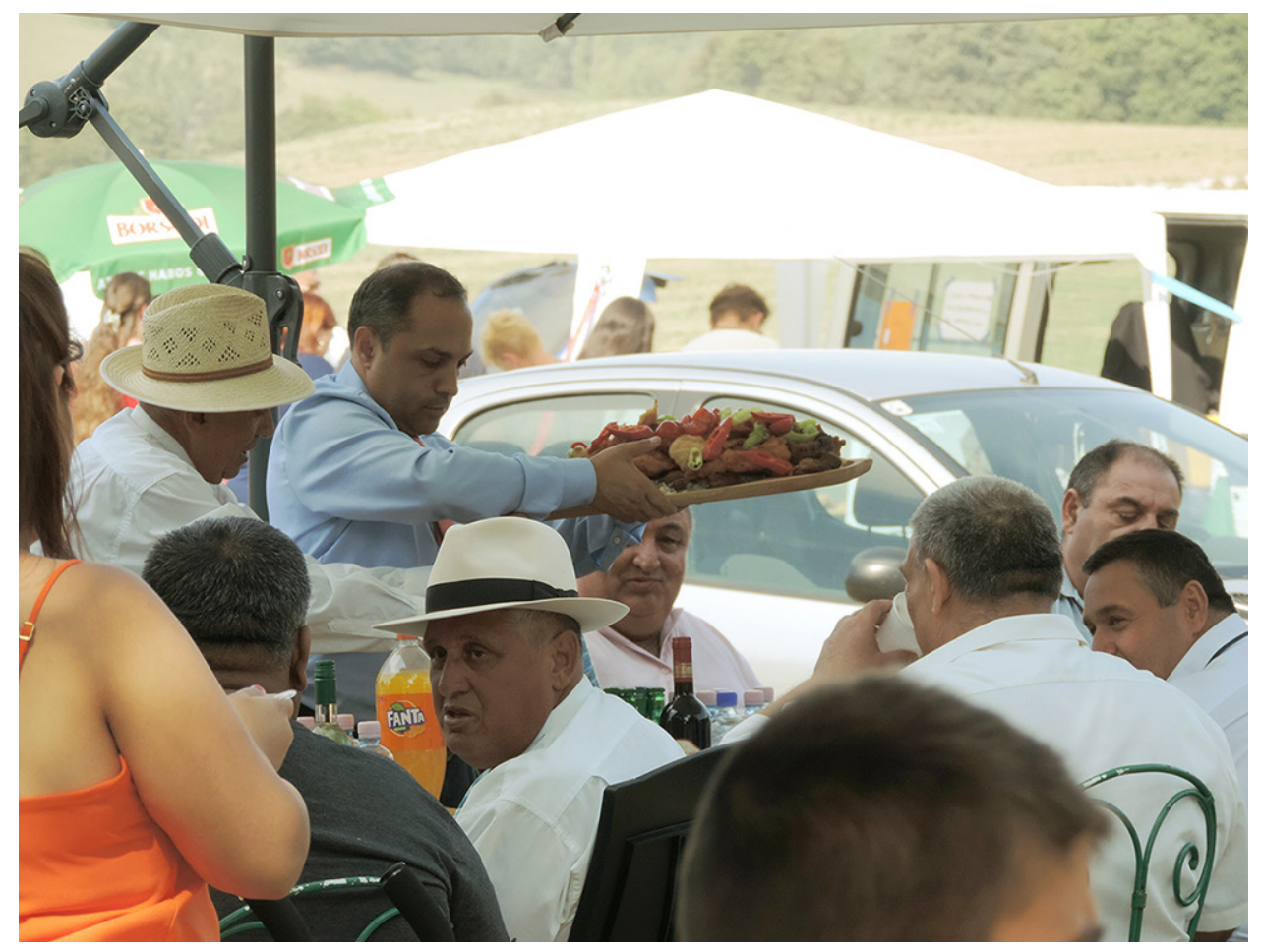

A table reserved for voivodes (Roma political leaders). Photo by István

Povedák, 2017.

determinative in a certain situation. Now there is rather an a-centric perspective, the interaction of a plurality of zones. This diversity and complexity lead to extremely complex and ambiguous places, and thus often also to clashes. Every sacred space is shared space." ${ }^{43}$ His argumentation is well supported by the analysis of the Csatka pilgrimage site. Few Christian sacred rites are known where the sacred and profane course of action would contrast as sharply with each other and divide the participants as much as the Csatka pilgrimage. The profane part here goes beyond the unloading fairs usually found in pilgrimage sites, or the restaurants, shops, hotels that appear in transnational pilgrimage sites. On the one hand, since pilgrims hardly visit Csatka on other days of the year, there is no permanent place of service here. On the other hand, the profane space and its events here are not just about eating and getting gifts, but binge drinking, dancing, and partying from dusk to dawn. There are several larger tents set up in the meadow next to the car park, each with a separate band. As the pilgrimage to Csatka was never just a sacred rite for the Roma, but also a reunion place for families scattered in different parts of the country (today different parts of the world), therefore, fun, singing and music have always been present according to memory. And due to the fact that there was practically no Roma ritual-either sacred or profane-in the country where Roma gathered on a similar scale, their other community affairs were also settled here for

43 Post et al., "Introduction," 6. 
practical reasons. Among the matters affecting the larger community, such is the election of the voivode (rarely nowadays), and among the family matters choosing the bride, and even the maidens fair. And the two events provide a new explanation for understanding why the richer Roma over-represent their wealth, and that the ornate attire is not just for the religious event. According to these, the "maidens for sale" had to wear festive clothes supplemented with a wreath of artificial flowers on their heads not only because of the representation of wealth but also because this was the sign they were waiting for a groom. ${ }^{44}$ Maiden fairs in Csatka are becoming rarer these days, but they were still common at the turn of the millennium. Several claimed that there had been no maiden fair in the last five to ten years, although one of our informants explicitly swore she had seen one more in person in 2015. An article in a local newspaper in 1979 accurately described that a bride was married to her husband for an average salary of roughly a year. First "visual inspection, then bargain on the girl, and cheering, screaming when the fair is ready." 45 "I raised the money all year to come to the bridal fair. My son gets a good salary, he wants to buy, and if he succeeds, we'll have a lot of fun. I have to get in with fifteen or twenty thousand, too..." - How much does a bride cost? "Well, like a good horse. If it is beautiful and shapely, it can be 35-40 thousand forints." ${ }^{46}$-And will the marriage work? "It's not the parents' business. Somehow they'll just come out." -No trial marriage? "Not then. That would bring shame to the parent. But the sale and handshake in Csatka is like the Tokaji Aszú in wine. So, brand." ${ }^{47}$

The "successful" maiden fair was followed by a wedding in the woods, and later an official state ceremony after returning home. An organic continuation of the forest wedding is the wedding party held in the meadow with music, dance, and naturally alcohol. From this point of view, we can discover an antecedent in these wedding rituals of today's musical dance entertainments.

However, the passing of the maiden fairs and forest weddings resulted in the

44 Szuhay, A magyarországi, 114.

45 Wér, A csatkai, 7.

46 The average gross earnings in 1979 were HUF 3,877 per month. http://www.ksh.hu/docs/ hun/xstadat/xstadat_hosszu/h_qli001.html?fbclid=IwAR1 cqN4gOKxRxGcmbVSUV7ps-Vq7gmZ3d9H7wxN0ID6xwZ1Un66D896Yo1w.

47 Wér, $A$ csatkai, 7. 
The Roma Pilgrimage to Csatka, Hungary

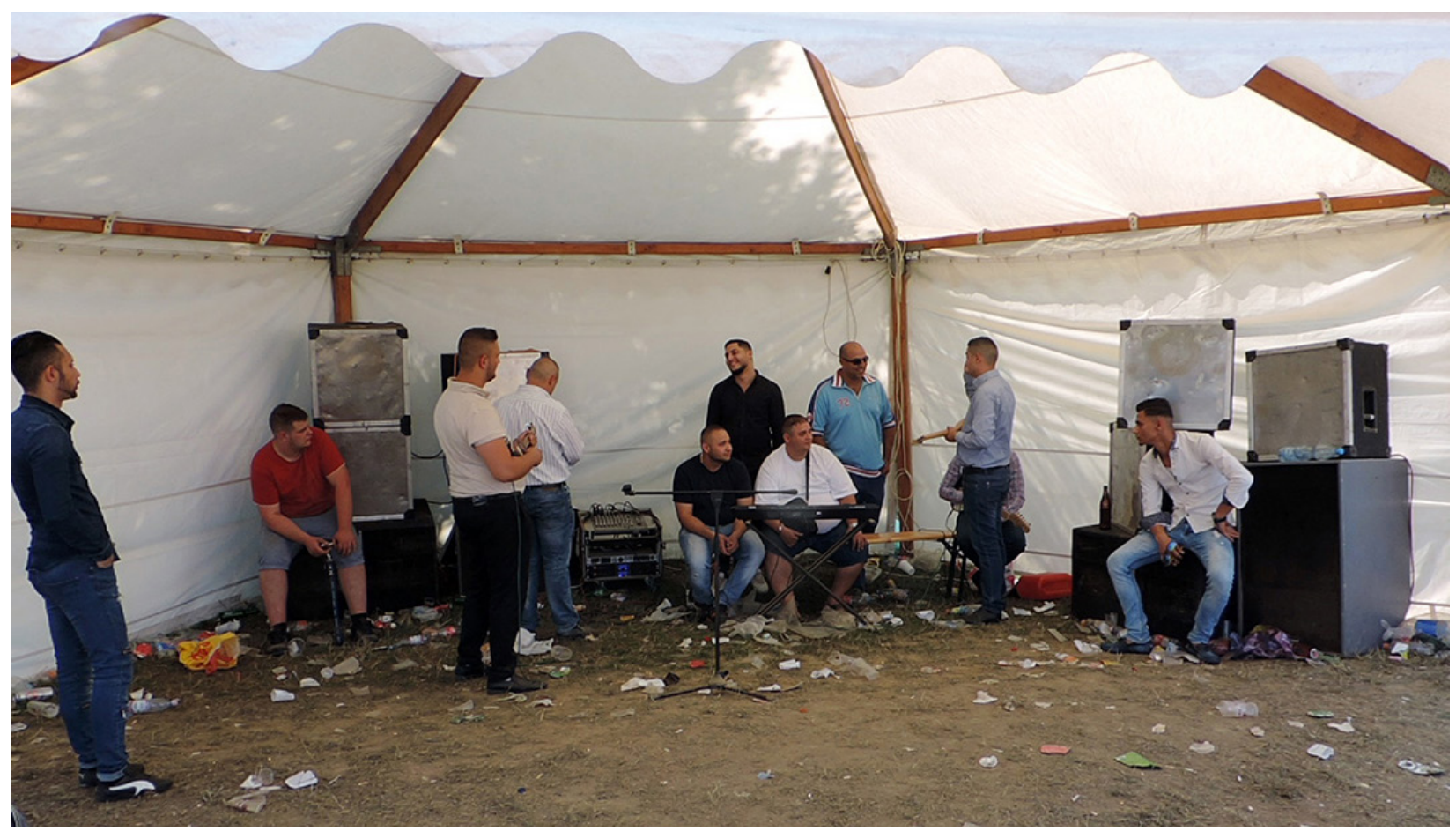

Bands set up in different tents on the hilltop. The party lasts until Sunday morning. Photo by István Povedák, 2017. emptying of the ritual. We are already experiencing a partially "meaning-lost" rites today, where the void caused by the disappearance of the weddings and the voivode elections was filled by the celebration of the collective Roma identity and togetherness. In the celebrating crowd, several Roma people wished "good luck, love, health, happiness, the blessing of the Virgin Mary to all Gypsies" sensitively and loudly, emphasizing with shouting.

Margry is right to mention that "[a]lthough pilgrimage was and still is basically an individual endeavor which does not generate inherent bonding among the traveling pilgrims, pilgrimage can also generate strong manifestations of sociability which influence the pilgrimage experience." ${ }^{38}$ However, in our case, the road to the pilgrimage place is not important anymore for the Roma, only the social dimension, the communitas that can be experienced at the place. ${ }^{49}$

This way live concerts mean more to the Roma than just mundane entertainment. The performance of a nationally known Roma singer turns their concert into a festival that strengthens and celebrates the Roma identity. As the Roma identity is lacking in the role models of historical heroes, Roma celebrities are considered to be one of the most important examples and orientation points. ${ }^{50}$ Famous celebrities

48 Margry, "To Be," 176.

49 Turner and Turner, Image and Pilgrimage in Christian Culture.

50 István Povedák, Színvak könyv. A cigány identitás mintázatai (Szeged: Szokeresz, 2019). 
like the singer LL. Junior, Kis Grófo, Gáspár Laci, or the YouTube stars of Gypsy turbo-folk music are role models who came from a difficult situation, but thanks to their persistent work, became successful. Moreover, as they proudly assume their Roma identity they are seen as modern heroes who overcome the limits of discrimination, with whom all the Roma can meet face to face and have fun with at Csatka. As there are no official, state-level memorial rites to nurture the identity of the Roma, these are replaced by — among other things — the Csatka pilgrimage. Similar to what Tim Edensor described in connection with banal nationalism, here too they experience and express their togetherness through popular culture in a semi-formal event, largely organized from the level of informal culture. ${ }^{51}$

However, the collective celebration of ethnic identity does not always elicit a positive evaluation among Gadjo pilgrims: "Unfortunately, my experience is that many people come to Csatka just for the party. Anyone who arrives with their Slovak license plate car at half past two at night stops just above the tents, then has party, dances, gets drunk well, then goes home in the morning. It's not because of religion. They call each other on the phone, 'Come, Little Pere is playing here,' or Csórike and the Sztojka and such, they also come from Borsod [the opposite side of Hungary]. They leave home even early in the evening to get here for the party." (50-year-old-man, Pápa)

\section{THE LOCAL COMMUNITY AND THE PILGRIMAGE}

When folklorists and cultural anthropologists analyze pilgrimages, the researcher focuses primarily on the toolkit of the rite, the far-flung pilgrims, their motivations, or the often syncretizing religious elements, and primarily the curiosity are observed. While in addition to the "guests," the "hosts," the attitude of the local community to the arrivals, to the event itself, remain much more in the background. ${ }^{52}$ This is no different in case of Csatka either. In almost all cases, the reports and reports in newspapers focus on the Roma crowd, their fun, their unusual,

51 Tim Edensor, National identity, Popular Culture and Everyday Life (Oxford, New York: Berg Publishers, 2002)

52 Cristina Sánchez-Carretero, "To Walk and to Be Walked... at the End of the World," in Heritage, Pilgrimage and the Camino to Finisterre: Walking to the End of the World, ed. Cristina Sánchez-Carretero (Springer, GeoJournal Library 117, 2015): 2. https://doi.org/10.1007/978-3-319-20212-9_1. 
60 | "Give me some beautiful holy images that are colorful, play music, and flash!"

The Roma Pilgrimage to Csatka, Hungary

"extraordinary," almost exotic nature, which practically corresponds to the Gypsy stereotypes existing in the media and public opinion. However, the local community barely appears. ${ }^{53}$ One of the reasons for this is that the Nativity of Mary pilgrimage has gradually been pushed out of the settlement of Csatka, and a crowd of pilgrims are just passing through the village and spending all their time at the chapel in the woods. On the other hand, after the change of regime in 1989, in parallel with the general religious tendencies, ${ }^{54}$ the official church rituals such as Holy Masses, baptisms and folk religiosity are also a declining attraction. The long-standing religion-preserving power of villages has diminished, village communities are aging, and their population number is declining. There are fewer and fewer parishioners and, let's add, fewer and fewer young people, but more elderly residents and believers. ${ }^{55}$ While until the 1970s the Csatka people were actively involved in the pilgrimage, the pilgrims also entered the village fair. However, along with the fact that the number of Oláh Gypsies became dominant among the pilgrims, the rites accompanying the pilgrimage also broke away from the village and concentrated exclusively on the forest. Presumably, the situation would be different if Csatka had a Roma population.

While at the beginning of the 20th century there are still data that the villagers also preferred to see the poorer Roma, by the 1990s the then-mayor of the village had already spoken of the pilgrimage as blessing the village with international fame and as a curse, as it requires a lot of energy and material expenditure. We may encounter a strikingly similar situation in the famous Les Saintes-Maries-de-la Mer in France where - as Wiley notes-many villagers "regard the Romani pilgrimage as an unwelcome invasion and occupation of their community." ${ }^{56}$ Although, while the tourists there in turn compensate with spending their money in local shops and restaurants, there is absolutely no tourist industry in Csatka. It is true that since

53 Gábor Bernáth and Vera Messing, Vágóképként, csak némában. Romák a magyarországi médiában (Budapest: Nemzeti és Etnikai Kisebbségi Hivatal, 1998).

54 István Kamarás, Kis Magyar religiográfia (Pécs: Pro Pannonia, 2003).

55 Kamarás, Kis.

56 Eric Wiley, "Romani Performance and Heritage Tourism: The Pilgrimage of the Gypsies at Les Saintes-Maries-de-la Mer," TDR-The Drama Review 49 (2005): 137, https://doi. org/10.1162/1054204053971126. 
pilgrims arrive by car and bus, they have had to pay parking money, but a significant part of the proceeds is taken away by cleaning up the rubbish and repairing the damage caused. A significant portion of the local population stays uninterested away from the pilgrimage; they don't rent outlets, and they no longer slaughter pigs for the occasion.

\section{CONCLUSION}

The pilgrimage in Csatka is one of the few pilgrimage sites in Hungary, which in recent years has not become a local celebration, but attracts pilgrims on national and even cross-border level. While in the first half of the 20th century it was a multi-ethnic (Roma, Hungarian, German, Slovak) pilgrimage site, from the 1970s onwards the Roma character gradually became more dominant. The change can be attributed, partly to the general religious transformation in which the folk church that still existed in the 1960s, the traditional pilgrimage and folk religiosity that were still active, lost their power to attract the masses. During socialism, the number of pilgrims gradually decreased in most of the pilgrimage sites in Hungary, however, in Csatka an ambivalent process could be observed. Due to the fact that Gadjo folk religiosity has lost the power to create social solidarity that it previously had, the number of Gadjo pilgrims has narrowed and the pilgrimage today activates only the elderly community of the surrounding settlements. In contrast, the communal rite of the Roma has continued to live on. It is very likely that without the presence of the Roma, Csatka would be just one of the ever-thriving, but now emptying pilgrimage sites visited by aging groups of believers. Apparently, pilgrimage moves other strata and differently among the Roma and the Gadjos. While today the majority of Gadjo pilgrims are older and mostly female, all ages are present among Roma.

Together with the ethnic shift, the general character of the Csatka pilgrimage also changed since the mid-20th century. Roma pilgrims consider different rites, spaces, actions, behaviors and symbolic forms to be of primary importance, and the pilgrimage itself is about something else for them at all.

The pilgrimage has a bipolar, well-separable sacral (purifying, protective, healing) 
62 "Give me some beautiful holy images that are colorful, play music, and flash!"

The Roma Pilgrimage to Csatka, Hungary

Children overlook the area of the holy well at Csatka. Photo by István Povedák, 2017.

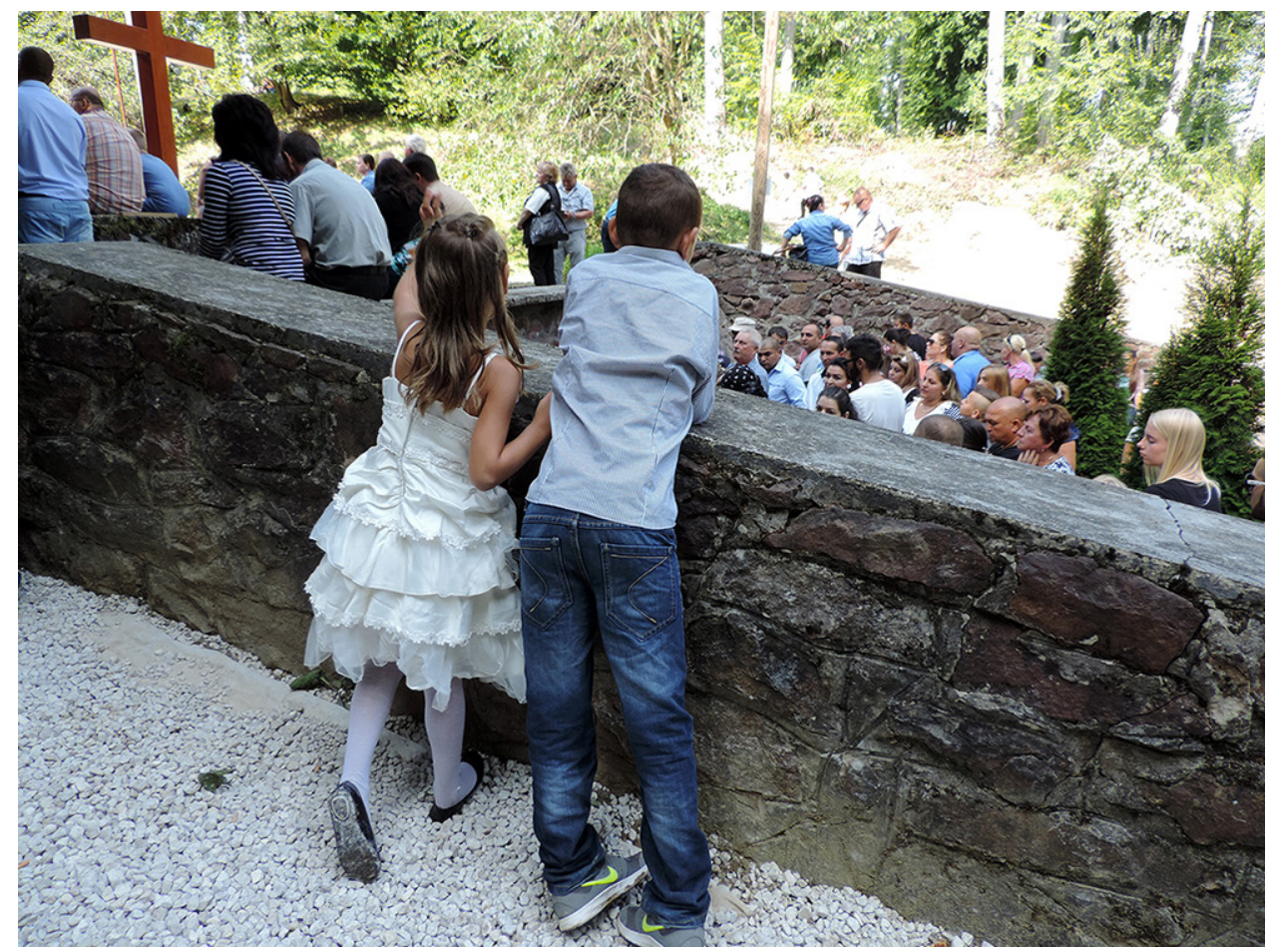

and secular (communal, identity-strengthening, entertaining) part in both place, the nature of rites, and ritual actions. However, the main motivation for participating in the pilgrimage is still the religious activities, which in the case of Roma exists in symbiosis with the strengthening of community cohesion. The all-night fun is just an additional - but much - anticipated - element of this. The bipolarity of the site has disturbed and continues to bother mainly Gadjo pilgrims and clerics to this day while it has an identity-strengthening role for the Roma.

The quiet devotion, the place of prayer, the chapel, and the holy well are located in the valley below, the secular revelry, the music, the dance, the sale, the "drinking until the morning" and the maiden fair took place on the hilltop. The pastoral theological potential of the pilgrimage, the organic involvement of the Roma in the sacred rites was discovered by the Catholic Church only surprisingly late. In recent years, the Saturday evening Mass in Lovari language has become regular, with Roma musicians playing contemporary Christian Romani music in Lovari, which encourages Roma to sing together and take an active part in the Mass. It is important to mention that most of the Roma pilgrims know and believe in the legend of the Virgin Mary apparition at the holy well, but the vast majority of them are not attached to the church as an institution. They have a Catholic identity, but they participate in church services only on extraordinary occasions. On other days of the year they do not attend Holy Mass and they do not know the liturgical precepts. Their 
attachment to the church is treated on a market basis. They show up once a year, making significant donations, buying gifts in exchange for hoping for a remission of all their sins: "What we commit a sin all year, here we try to make amends for it. This is the one day we spend here, it fills us with spirit and faith for the whole year." (47-year-old-man, Mezőfalva) It can be said they believe without belonging. ${ }^{57}$

The Csatka pilgrimage attracts all strata of Oláh Roma from the aristocrats to the poorest families. They all feel necessary to over-represent their wealth, feel pressure to buy and consume at the event. In spite of the fact that the event highlights class divisions of the Roma community it does not cause conflicts. The pilgrimage to Csatka, in the words of Paul Post, is a real "vessel ritual" that-in addition to the original, religious heritage-contains elements that strengthen ethnic identity, connected to politics or to entertainment. For the Roma, the role of pilgrimage in keeping the community together is significantly more pronounced than in any other pilgrimage site in Hungary. While in the past, voivodes were elected here, today a meeting of regional Roma aristocrats is held almost every year, but Roma NGOs and sometimes politicians also represent themselves. At the initiative of a Roma NGO, the Chapel of John Paul II or as pilgrims generally call the "Gypsy chapel" was erected. The Roma celebrities who perform small concerts during the pilgrimage are also significant from the Roma ethnic identity's perspective as-in the absence of their own ethnic historical heroes-they are a primary orientation point for the Roma. As Roma cannot fully identify with Hungarian national holidays, with the Hungarian national heroes, they experience their ethnic identity within the framework of a Christian religious ritual. This is made possible by their still sufficiently strong cultural-Christian identity.

In addition to its sacral function, the pilgrimage in Csatka is one of the most important Roma social gatherings of the year, a real Gypsy festival. As Aurél Vajkai put it in 1940, "the crowd, the multitude, the unpredictable abundance of like-minded people are the recipients; the sense of community, of belonging, flares up in the newcomer, which he has never experienced with such force." 58

57 Grace Davie, "Believing without Belonging: Is This the Future of Religion in Britain?" Social Compass 37, no. 4 (1990): 455-469. https://doi.org/10.1177/003776890037004004.

58 Vajkai, "A csatkai búcsú." 
64 "Give me some beautiful holy images that are colorful, play music, and flash!"

The Roma Pilgrimage to Csatka, Hungary

\section{BIBLIOGRAPHY}

Bárth, János. "A katolikus magyarság vallásos életének néprajza.” In Magyar Néprajz. VII. Folklór 3. Népszokás, néphit, népi vallásosság, edited by Attila Paládi-Kovács, 331-424. Budapest: Akadémiai Kiadó, 1990.

Bernáth, Gábor and Vera Messing. Vágóképként, csak némában. Romák a magyarországi médiában. Budapest: Nemzeti és Etnikai Kisebbségi Hivatal, 1998.

Bowman, Marion and Tiina Sepp. "Caminoisation and Cathedrals: Replication, the Heritagisation of Religion, and the Spiritualisation of Heritage." Religion 49, no. 1 (2019): 74-98. https://doi.org/10.1080/0048721X.2018.1515325.

Sánchez-Carretero, Cristina, ed. Heritage, Pilgrimage and the Camino to Finisterre: Walking to the End of the World. Springer, GeoJournal Library 117, 2015. https://doi.org/10.1007/978-3-319-20212-9.

. "To Walk and to Be Walked... at the End of the World." In Heritage, Pilgrimage and the Camino to Finisterre: Walking to the End of the World, ed. Cristina Sánchez-Carretero, 1-20. Springer, GeoJournal Library 117, 2015. https://doi.org/10.1007/978-3-319-20212-9_1.

Davie, Grace. "Believing without Belonging: Is This the Future of Religion in Britain?" Social Compass 37, no. 4 (1990): 455-469. https://doi.org/ 10.1177/003776890037004004.

Edensor, Tim. National Identity, Popular Culture and Everyday Life. Oxford, New York: Berg Publishers, 2002.

Erdős, Kamill. "Cigány törvényszék. Romani-Kris.” Néprajzi Közlemények 4, no. 1-2 (1959): 203-215.

Györke, Zoltán. "Csatka igazi arca." Dolgozók Lapja (April 08, 1972): 4.

Havasházi, László. "Ki esketett?" Dolgozók Lapja (September 16, 1961): 5. 
Ivakhiv, Adrian. "Nature and Self in New Age Pilgrimage." Culture and Religion 4, no. 1 (2003): 93-118. https://doi.org/10.1080/01438300302812.

Kamarás, István. Kis Magyar religiográfia. Pécs: Pro Pannonia, 2003.

Margry, Peter Jan, ed. Shrines and Pilgrimage in the Modern World: New Itineraries into the Sacred. Amsterdam: Amsterdam University Press, 2008. https://doi. org/10.5117/9789089640116.

_. "Secular Pilgrimage: A Contradiction in Terms?" In Shrines and Pilgrimage in the Modern World: New Itineraries into the Sacred, edited by Peter Jan Margry, 13-46. Amsterdam: Amsterdam University Press, 2008. https:// doi.org/10.5117/9789089640116.

. "To Be or Not to Be... a Pilgrim: Spiritual Pluralism Along the Camino Finisterre and the Urge for the End." In Heritage, Pilgrimage and the Camino to Finisterre: Walking to the End of the World, edited by Cristina SánchezCarretero, 175-211. Springer, GeoJournal Library 117, 2015. https://doi. org/10.1007/978-3-319-20212-9_8.

Mogyorósi, Ágnes. “A csatkai cigánybúcsú.” Erdélyi Múzeum 76, no. 1 (2014): 56-68.

Nolan, Mary Lee and Sidney Nolan. "Religious Sites as Tourism Attractions in Europe." Annals of Tourism Research 19, (1992): 68-78. https://doi. org/10.1016/0160-7383(92)90107-Z.

Olsen, Daniel H. and Dallen J. Timothy. “Tourism and Religious Journeys.” In Tourism, Religion and Spiritual Journeys, edited by Daniel H. Olsen and Dallen J. Timothy, 1-21. New York: Routledge, 2006.

Pereszlényi, Márta. “Adatok a csatkai búcsúhoz," Ethnographia 50, no. 1 (1941): 284-285.

Perger, Gyula. "A hívő nép és a kételkedő egyház. A csatkai csoda egyházi vizsgálatai.” In Liturgikus Örökségünk 21, edited by Iváncsó István, 189-238. Nyíregyháza: Görög Katolikus Hittudományi Főiskola, 2017. 
66 | "Give me some beautiful holy images that are colorful, play music, and flash!"

The Roma Pilgrimage to Csatka, Hungary

Post, Paul, Philip Nel, and Walter van Beek. "Introduction.” In Contested Identities: Space and Ritual Dynamics in Europe and Africa, edited by Paul Post, Philip Nel, and Walter van Beek, 1-25. Trenton: Africa World Press, 2014.

Povedák, István. "From Attila to the Hearth Chakra. Postmodern Pilgrimages." Acta Ethnographica Hungarica 59, no. 2 (2014): 371-388. https://doi.org/10.1556/ AEthn.2013.001.

. "A Pan-Hungarian 'Vessel Ritual' in Romania." In Politics, Feasts, Festivals, edited by Gábor Barna and István Povedák, 121-135. Szeged: MTA-SZTE Vallási Kultúrakutató Csoport, 2014.

. Színvak könyv. A cigány identitás mintázatai. Szeged: Szokeresz, 2019.

Rountree, Kathryn. "Journeys to the Goddess: Pilgrimage and Tourism in the New Age." In On the Road to Being There: Studies in Pilgrimage and Tourism in Late Modernity, edited by William H. Swatos, 33-60. Leiden: Brill, 2006.

Stausberg, Michael. Religion and Tourism: Crossroads, Destinations and Encounters. London and New York: Routledge, 2011. https://doi.org/10.4324/ 9780203854785 .

Székely, János. Cigány népismeret. Te del o Del baxt! Budapest: Szent István Társulat, 2010.

Szuhay, Péter. A magyarországi cigányság kultúrája: etnikus kultúra vagy a szegénység kultúrája? Budapest: Panoráma, 1999. . Sosemlesz Cigányország. Budapest: Osiris, 2012.

Takáts, Márton. A csatkai szent kut és kápolna eredete, s az ott történt csodák és látványosságok hủ leirása. Győr: Sauervein Géza, n.d. [1862].

Turner, Victor and Edith Turner, Image and Pilgrimage in Christian Culture. Anthropological Approaches. New York: Columbia University Press, 1978.

Vajkai, Aurél. “A csatkai búcsú. Adatok a népi orvosláshoz.” Ethnographia 51, no. 1 (1940): 50-73. 
Vukonić, Boris. Tourism and Religion. Oxford, New York, Tokyo: Pergamon, 1996.

Wettich, Thorsten. "Luther was here': The Making of Lutherweg as a Spiritual and Commemorative Pilgrimage." Journal of the Irish Society for the Academic Study of Religions (in preparation, 2020).

Wér, Vilmos. “A csatkai búcsún.” Dolgozók Lapja (September 16, 1979): 7.

Wiley, Eric. "Romani Performance and Heritage Tourism: The Pilgrimage of the Gypsies at Les Saintes-Maries-de-la Mer.” TDR-The Drama Review 49, no. 2 (2005): 135-158. https://doi.org/10.1162/1054204053971126. 